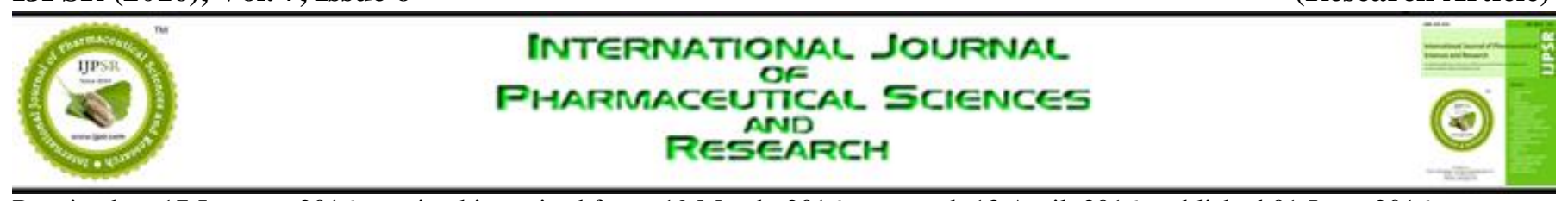

Received on 17 January, 2016; received in revised form, 19 March, 2016; accepted, 13 April, 2016; published 01 June, 2016

\title{
SYNTHESIS AND ANTIMICROBIAL ACTIVITY OF SOME QUINOLINE DERIVATIVES
}

Indu Singh ${ }^{* 1}$ and Arun Kumar ${ }^{2}$

Department of Chemistry ${ }^{1}$, Janta Vedic College ,Baraut - 250611, Baghpat, India Department of Community ${ }^{2}$, Medicine, L.L.R.M. Medical College, Meerut - 250004, U.P, India

Keywords:

Quinoline, Azetidinone, Antibacterial activity, Antifungal activity

Correspondence to Author:

Dr Indu Singh

Assistant Professor

Department of Chemistry

JV College, Baraut (Baghpat), U.P., India

Email: drindusinghmrt@gmail.com
ABSTRACT: Cyclocondensation of 5-6 and 7-8 with chloroacetyl chloride in presence of triethylamine give 9-10 and 11-12 respectively. All the synthesized compounds 1-12 have been screened for their antibacterial as well as antifungal activities and compared with reference drugs streptomycin and fusidic acid respectively. These synthesized compounds were screened for their antibacterial activity against $S$. aureus and B. subtillis and antifungal activity against $A$. niger and $C$. albicans. The melting points were determined in open glass capillaries tubes. Purity of the compounds was checked by thin layer chromatography (TLC) on silica gel G plates and spots were located by using iodine chamber. All the newly synthesized compounds were confirmed by elemental $(\mathrm{C}, \mathrm{H}, \mathrm{N})$ and spectral IR, ${ }^{1} \mathrm{HNMR}$ analysis. In this series compound 10 showed better antibacterial activity than reference drug streptomycin and compounds 10 and 12 were found to be more potent antifungal agents than reference drug fusidic acid.
INTRODUCTION: Quinoline derivatives represent one of the most active classes of compounds possessing a wide spectrum of biological activity. They are widely used in pharmaceuticals and agrochemicals. Several reports have been published on the biological activity of quinoline derivatives including their antimicrobial ${ }^{1,2}$, antibacterial ${ }^{3}$, anti-inflammatory ${ }^{4}$, anticancer ${ }^{5}$ and anticonvulsant ${ }^{6}$ activities. Similarly, various azetidinones have attracted considerable attention as they are also endowed with a wide range of pharmaceutical activities including anticonvulsant ${ }^{7}$, antimicrobial 8 , anti-inflammatory 9, 10 and antibacterial ${ }^{11,12}$ activities.

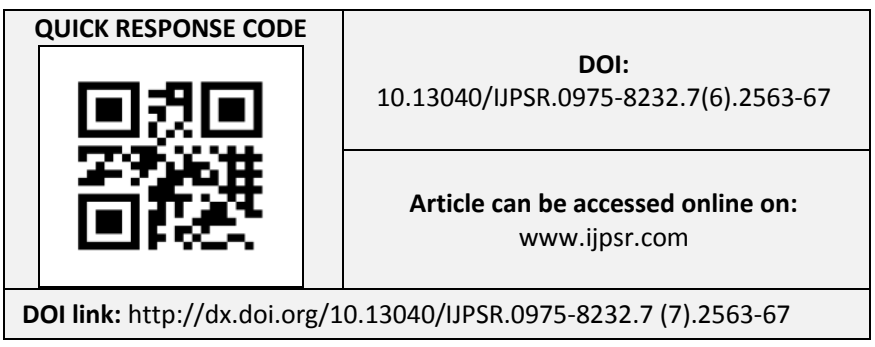

Looking to the medicinal importance of quinolines and azetidinones, we report here the synthesis of new class of heterocyclic molecules in which all of these moieties are present and try to develop potential bioactive molecules.

\section{METERIAL AND METHODS:}

All reagents and solvents were of analytical grade and used directly. Reactions were routinely performed in oven-dried borosil glassware. The melting points of compounds were determined in open capillaries with the help of thermonic melting point apparatus and were uncorrected. The homogeneity of all newly synthesized compounds was routinely checked by thin layer chromatography (TLC) on silica gel G plates and spots were located by using iodine chamber. Elemental analysis $(\mathrm{C}, \mathrm{H}, \mathrm{N})$ of all the synthesized compounds were determined by Perkin-Elmer 2400 elemental analyzer, and results were found within the $\pm 0.4 \%$ of theoretical values. The IR spectra were recorded on a Beckman Acculab-10 
spectrometer $\left(v_{\max }\right.$ in $\left.\mathrm{cm}^{-1}\right)$ and the ${ }^{1} \mathrm{H}$ NMR spectra were recorded by Brucker DPX-300 MHz using $\mathrm{CDCl}_{3}$ as solvent.

\section{Pharmacological studies:}

All the newly synthesized metal complexes were tested for their antimicrobial activity. The effects of unknown metal complexes were compared with the standard drug streptomycin for bacteria and fusidic acid for fungi. Antibacterial activity was performed against $S$. aureus, B. subtillis and antifungal activity against $A$. niger and $C$. albicans. The antibacterial activity was assayed by cup plate method ${ }^{13}$ and antifungal activity was assayed by standard agar disc diffusion method ${ }^{14}$.

\section{RESULTS AND DISCUSSION:}

The antibacterial activity of compounds 1-12 and the standard drug streptomycin, was carried out against $S$. aureus and B. substillis. Results showed the varying degree of antibacterial activity of all the compounds tested (table-1). From the result it is clear that compound 10 showed excellent antibacterial activity, better than the standard drug and good inhibition zones against all the bacterial strains. Compounds 9,11 and 12 showed good antibacterial activity against all the tested organism. The other compounds of this series showed a moderate activity as compared to standard drug. Compounds 1-12 along with the reference drug fusidic acid were also tested for antifungal activity against $A$. niger and $C$. albicans (Table 1). The results of the antifungal screening revealed that all the tested compound 1-12 showed moderate to good antifungal properties. Out of these compounds tested, compounds 10 and 12 were found to be more potent antifungal agents against all the fungal strains than the reference drug.

TABLE 1: ANTIBACTERIAL AND ANTIFUNGAL ACTIVITY OF COMPOUNDS 1-12

\begin{tabular}{cccccc}
\hline Compounds & $\mathbf{R}$ & \multicolumn{2}{c}{ Bacterial inhibition zone/mm } & \multicolumn{2}{c}{ Fungal inhibition zone/mm } \\
\cline { 2 - 6 } & & S. aureus & B. substillis & A. niger & C. albicans \\
\hline 1 & $\mathrm{H}$ & 15 & 18 & - & 20 \\
2 & $\mathrm{CH}_{3}$ & 22 & - & 20 & - \\
3 & $\mathrm{H}$ & 24 & - & 25 & - \\
4 & $\mathrm{CH}_{3}$ & - & 27 & - & 23 \\
5 & $\mathrm{H}$ & 28 & 25 & 28 & 27 \\
6 & $\mathrm{CH}_{3}$ & 30 & 27 & 29 & - \\
7 & $\mathrm{H}$ & 32 & - & 32 & 35 \\
8 & $\mathrm{CH}_{3}$ & & 31 & 33 & 39 \\
9 & $\mathrm{H}$ & 35 & 34 & 36 & 40 \\
10 & $\mathrm{CH}_{3}$ & 42 & 39 & 40 & 34 \\
11 & $\mathrm{H}$ & 39 & 35 & 38 & 38 \\
12 & $\mathrm{CH}_{3}$ & 38 & 36 & 37 & \\
Streptomycin & & 39 & 37 & & \\
Fusidic acid & & & &
\end{tabular}

\section{Preparation of Benzylic azides/2-methyl benzylic azide:}

To a solution of benzyl alcohol (1.0 equiv) in Dichloromethane $(2.6 \mathrm{ml})$ was added $\mathrm{PBr}_{3}(0.34$ equiv) at room temperature. The reaction mixture was stirred for $1 \mathrm{~h}$ and then the solvent was removed under reduce pressure. The crude product was dissolved in DMSO (2.6 ml) and $\mathrm{NaN}_{3}(2.5$ equiv) was added at $0^{0} \mathrm{C}$. The mixture was stirred $16 \mathrm{~h}$ and diluted with water and extracted with EtOAc. The product was dried with $\mathrm{Na}_{2} \mathrm{SO}_{4}$ and concentrated under reduced pressure to obtain the crude material which was purified on silica gel to yield the benzylic azides.
Preparation of Ethyl quinoline-3-carboxylate (1) To a solution of substituted benzylic azide (1.0 $\mathrm{mol})$ in toluene $(20 \mathrm{ml})$ were added $\mathrm{TfOH}(1.0 \mathrm{~mol})$ at room temperature respectively. The reaction mixtures were stirred until the evolution of $\mathrm{N}_{2}$ gas bubbles subsided. The reaction mixtures were stirred for $3 \mathrm{~h}$ and then added with sat. $\mathrm{NaHCO}_{3}$ to dilute the reaction. The reaction mixtures were extracted with EtOAc $(40 \mathrm{ml})$ and then DDQ was added and stirred for $5 \mathrm{~min}$. The solvent was removed under reduced pressure to obtain the crude material which as purified on silica gel using hexane to yield compounds 1-2. 
Yield (67), m.p: $156{ }^{0} \mathrm{C}$; IR (KBr) max in $\mathrm{cm}^{-1} 1296$ $(\mathrm{C}-\mathrm{N}), \quad 1575 \quad(-\mathrm{N}=\mathrm{CH}), \quad 1724 \quad(-\mathrm{C}=\mathrm{O}), \quad 1784$ (COOEt), 3017 (C-H aromatic); ${ }^{1} \mathrm{H}-\mathrm{NMR}$ (DMSO$\left.\mathrm{d}_{6} \delta \mathrm{ppm}\right): 3.25\left(\mathrm{~s}, 5 \mathrm{H}, \mathrm{OC}_{2} \mathrm{H}_{5}\right), 7.72-8.30(\mathrm{~m}, 6 \mathrm{H}$, ArH); Anal. Calcd. for $\mathrm{C}_{12} \mathrm{H}_{11} \mathrm{NO}_{2}$ : C, 71.63; H, 5.51; N, 6.96: Found: C, 71.66; H, 5.54; N, 6.94\%.

Ethyl 8-methylquinoline-3-carboxylate (2):

Yield (61), m.p: $173^{0} \mathrm{C}$; IR (KBr) max in $\mathrm{cm}^{-1} 1299$ $(\mathrm{C}-\mathrm{N}), \quad 1573 \quad(-\mathrm{N}=\mathrm{CH}), \quad 1720 \quad(-\mathrm{C}=\mathrm{O}), \quad 1787$ (COOEt), 3015 (C-H aromatic); ${ }^{1} \mathrm{H}-\mathrm{NMR}$ (DMSO$\left.\mathrm{d}_{6} \delta \mathrm{ppm}\right): 2.23\left(\mathrm{~s}, 3 \mathrm{H}, \mathrm{CH}_{3}\right), 3.27\left(\mathrm{~s}, 5 \mathrm{H}, \mathrm{OC}_{2} \mathrm{H}_{5}\right)$, 7.70-8.31 (m, 5H, ArH); Anal. Calcd. for $\mathrm{C}_{13} \mathrm{H}_{13} \mathrm{NO}_{2}$ : C, 72.54; H, 6.09; N, 6.51: Found: C, 72.56; H, 6.12; N, 6.54\%.
Preparation of Quinoline-3-carbohydrazide (3): A mixture of compounds1-2 $(1.0 \mathrm{~mol})$ and hydrazine hydrate $(2.0 \mathrm{~mol})$ in absolute ethanol $(80$ $\mathrm{ml}$ ) was refluxed for $20 \mathrm{~h}$ respectively. The reaction mixtures were cooled and poured on crushed ice and separated solids were filtered, washed with cold water, dried and recystalliized from ethyl acetate to yield compound 3-4. Yield (56), m.p: $168^{0} \mathrm{C}$; IR (KBr) max in $\mathrm{cm}^{-1} 1295$ (C-N), $1577(-\mathrm{N}=\mathrm{CH}), 1726(-\mathrm{C}=\mathrm{O}), 3013$ (C-H aromatic), 3324 (-C-NH); ${ }^{1} \mathrm{H}-\mathrm{NMR}$ (DMSO-d $\left.{ }_{6} \delta \mathrm{ppm}\right): 4.65$ (hump, 2H, $\mathrm{NH}_{2}$ exchangeable), 7.46 (br, 1H, NH exchangeable), 7.71-8.30 (m, 6H, ArH); Anal. Calcd. for $\mathrm{C}_{10} \mathrm{H}_{9} \mathrm{~N}_{3} \mathrm{O}:$ C, 64.16; H, 4.85; N, 22.45: Found: C, 64.18; H, 4.84; N, 22.44\%.

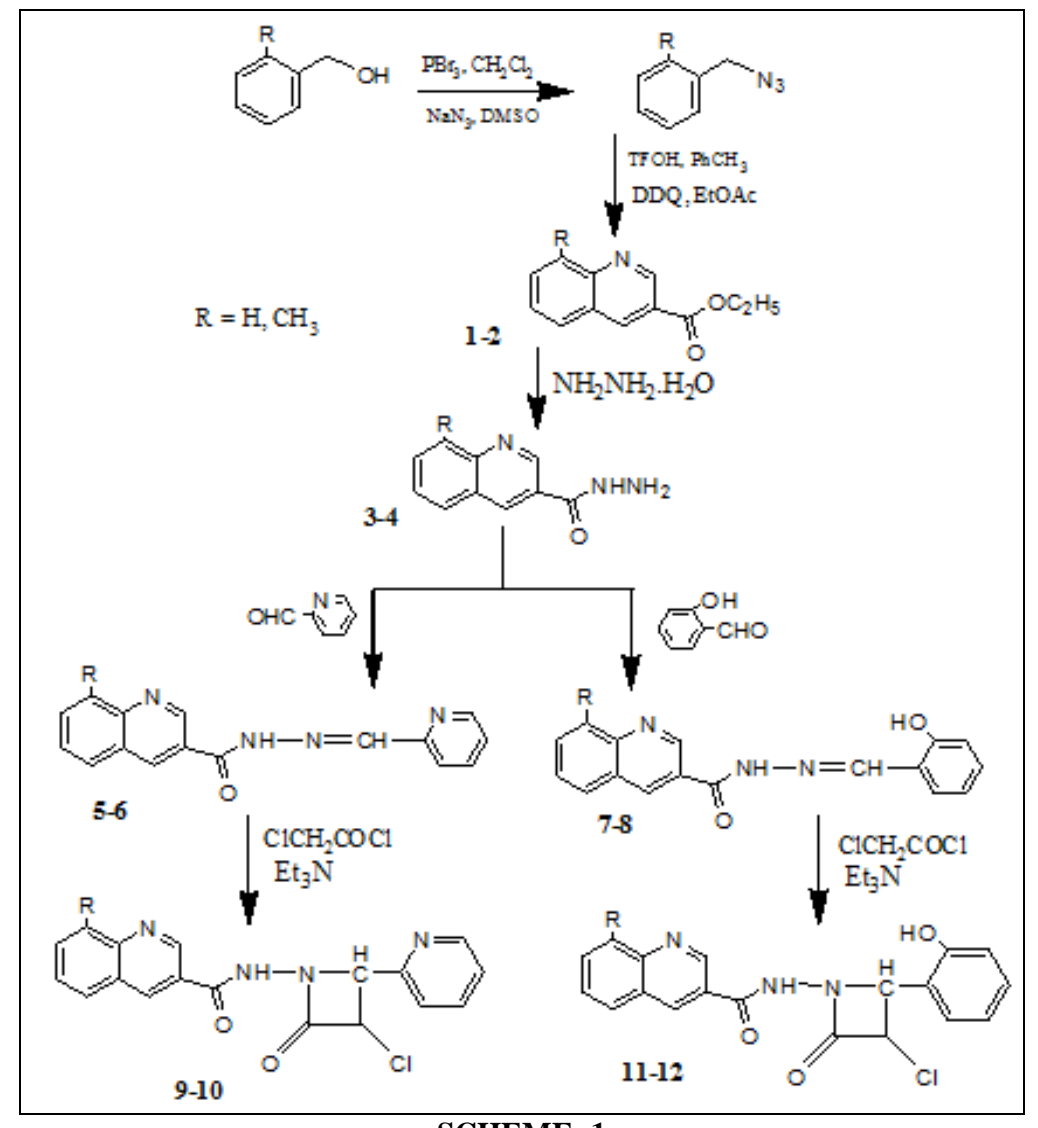

Methylquinoline-3-carbohydrazide (4):

Yield (52), m.p: $185^{\circ} \mathrm{C}$; IR (KBr) max in $\mathrm{cm}^{-1} 1297$ $(\mathrm{C}-\mathrm{N}), 1579(-\mathrm{N}=\mathrm{CH}), 1723(-\mathrm{C}=\mathrm{O}), 3010(\mathrm{C}-\mathrm{H}$ aromatic), 3326 (-C-NH); ${ }^{1} \mathrm{H}-\mathrm{NMR}$ (DMSO-d $\mathrm{d}_{6} \delta$ ppm): 2.21 (s, $3 \mathrm{H}, \mathrm{CH}_{3}$ ), 4.65 (hump, $2 \mathrm{H}, \mathrm{NH}_{2}$ exchangeable), 7.40 (br, 1H, NH exchangeable), 7.72-8.31 (m, 5H, ArH); Anal. Calcd. for $\mathrm{C}_{11} \mathrm{H}_{11} \mathrm{~N}_{3} \mathrm{O}$ : C, 65.66; H, 5.51; N, 20.88: Found: C, 65.69; H, 5.54; N, 20.85\%.
Preparation of N'-(pyridine-2-ylmethylene) quinoline-3-carbohydrazide (5):

A solution of compounds 3-4 $(1.0 \mathrm{~mol})$ in methanol $(50 \mathrm{ml})$ were refluxed with picolinaldehyde $(1.0$ $\mathrm{mol})$ in the presence of glacial acetic acid $(4 \mathrm{ml})$ for $11 \mathrm{~h}$ respectively. The reaction mixtures were concentrated, cooled and then poured into ice water. The separated solids were filtered and recrystallized from ethanol to yield compounds 5-6. 
Yield (47), m.p: $192^{\circ} \mathrm{C}$; IR (KBr) $\max$ in $\mathrm{cm}^{-1} 1295$ $(\mathrm{C}-\mathrm{N}), 1512(\mathrm{~N}-\mathrm{N}), 1573(-\mathrm{N}=\mathrm{CH}), 1726(-\mathrm{C}=\mathrm{O})$, 3013 (C-H aromatic), 3322 (-C-NH); ${ }^{1} \mathrm{H}-\mathrm{NMR}$ (DMSO-d 6 $\delta$ ppm): 7.44 (d, 1H, NH), 7.71-8.33 (m, 10H, ArH), 8.63 (s, 1H, -N=CH); Anal. Calcd. for $\mathrm{C}_{16} \mathrm{H}_{12} \mathrm{~N}_{4} \mathrm{O}$ : $\mathrm{C}, 69.55 ; \mathrm{H}, 4.38 ; \mathrm{N}, 20.28$ : Found: C, 69.56; H, 4.39; N, 20.24\%.

8-Methyl - N'- (pyridine - 2 - ylmethylene) quinoline -3-carbohydrazide (6):

Yield (44), m.p: $195^{\circ} \mathrm{C}$; IR (KBr) ${ }_{\text {max }}$ in $\mathrm{cm}^{-1} 1294$ $(\mathrm{C}-\mathrm{N}), 1507(\mathrm{~N}-\mathrm{N}), 1577(-\mathrm{N}=\mathrm{CH}), 1728(-\mathrm{C}=\mathrm{O})$, 3016 (C-H aromatic), 3324 (-C-NH); ${ }^{1} \mathrm{H}-\mathrm{NMR}$ (DMSO-d 6 $\delta$ ppm): $2.25\left(\mathrm{~s}, 3 \mathrm{H}, \mathrm{CH}_{3}\right), 7.43(\mathrm{~d}, 1 \mathrm{H}$, $\mathrm{NH}), 7.73-8.30(\mathrm{~m}, 9 \mathrm{H}, \operatorname{ArH}), 8.61(\mathrm{~s}, 1 \mathrm{H},-$ $\mathrm{N}=\mathrm{CH}$ ); Anal. Calcd. for $\mathrm{C}_{17} \mathrm{H}_{14} \mathrm{~N}_{4} \mathrm{O}: \mathrm{C}, 70.33 ; \mathrm{H}$, 4.86; N, 19.30: Found: C, 70.36; H, 4.84; N, $19.34 \%$.

N'-(Pyridine - 2 - ylmethylene) quinoline-3carbohydrazide (7):

A mixture of compound 3-4 $(1.0 \mathrm{~mol})$ and different substituted benzyldehyde $(1.0 \mathrm{~mol})$ in $50 \mathrm{ml}$ of methanol along with glacial acetic acid (2-3 drops) was refluxed for $12 \mathrm{~h}$. The reaction mixtures were cooled. The solids were obtained then filtered, washed with water, dried and recrystallized from appropriate solvents to furnish compounds 7-8.

Yield (), m.p: $214^{0} \mathrm{C}$; IR (KBr) $\max$ in $\mathrm{cm}^{-1} 1292$ (C$\mathrm{N}), 1505(\mathrm{~N}-\mathrm{N}), 1574(-\mathrm{N}=\mathrm{CH}), 1723(-\mathrm{C}=\mathrm{O})$, 3012 (C-H aromatic), $3325(-\mathrm{C}-\mathrm{NH}), 3450(\mathrm{OH})$; ${ }^{1} \mathrm{H}-\mathrm{NMR}$ (DMSO-d $\left.\mathrm{d}_{6} \delta \mathrm{ppm}\right): 7.41(\mathrm{~d}, 1 \mathrm{H}, \mathrm{NH})$, 7.70-8.29 (m, 10H, ArH), $8.66(\mathrm{~s}, 1 \mathrm{H},-\mathrm{N}=\mathrm{CH})$, 12.20 (s, $1 \mathrm{H}, \mathrm{OH}$ ); Anal. Calcd. for $\mathrm{C}_{16} \mathrm{H}_{12} \mathrm{~N}_{4} \mathrm{O}$ : C, 69.55; H, 4.38; N, 20.28: Found: C, 69.57; H, $4.34 ; \mathrm{N}, 20.26 \%$.

8-Methyl-N'-(pyridine-2 -ylmethylene) quinoline -3-carbohydrazide (8):

Yield (45), m.p: $221^{0} \mathrm{C}$; IR (KBr) max $_{\text {in }} \mathrm{cm}^{-1} 1297$ $(\mathrm{C}-\mathrm{N}), 1509(\mathrm{~N}-\mathrm{N}), 1577(-\mathrm{N}=\mathrm{CH}), 1726(-\mathrm{C}=\mathrm{O})$, 3014 (C-H aromatic), 3326 (-C-NH), $3455(\mathrm{OH})$; ${ }^{1} \mathrm{H}-\mathrm{NMR}$ (DMSO-d $\mathrm{d}_{6} \delta \mathrm{ppm}$ ): $2.23\left(\mathrm{~s}, 3 \mathrm{H}, \mathrm{CH}_{3}\right)$, $7.46(\mathrm{~d}, 1 \mathrm{H}, \mathrm{NH}), 7.73-8.31$ (m, 9H, ArH), 8.64 (s, $1 \mathrm{H},-\mathrm{N}=\mathrm{CH}), 12.25(\mathrm{~s}, 1 \mathrm{H}, \mathrm{OH})$; Anal. Calcd. For $\mathrm{C}_{17} \mathrm{H}_{14} \mathrm{~N}_{4} \mathrm{O}$ : C, 70.33; H, 4.86; N, 19.30: Found: C, 70.36; H, 4.84; N, 19.34\%.
Preparation of N-(3-Chloro-2-oxo-4-(pyridine-2yl)azetidin-1-yl)quinoline-3-carboxamide (9):

Take the solution of chloroacetyl chloride $(1.0 \mathrm{~mol})$ in dry dioxane $(50 \mathrm{ml})$, was added drop wise during $2 \mathrm{~h}$ to a well stirred solution of compounds 5-6 (1.0 mol) and compounds 7-8 (1.0 mol) respectively. The reaction mixtures were stirred continuously $4 \mathrm{~h}$, cooled and poured it into water. A solids were obtained, filtered and washed with water and recystallized from acetone to yield compounds 9-10 and compounds 11-12.

Yield (43), m.p: $231{ }^{0} \mathrm{C}$; IR (KBr) $\max$ in $\mathrm{cm}^{-1} 661$ (C-Cl), 1299 (C-N), $1513(\mathrm{~N}-\mathrm{N}), 1571(-\mathrm{N}=\mathrm{CH})$, $1729(-\mathrm{C}=\mathrm{O}), 3012(\mathrm{C}-\mathrm{H}$ aromatic), $3324(-\mathrm{C}-\mathrm{NH})$, $3458(\mathrm{OH}) ;{ }^{1} \mathrm{H}-\mathrm{NMR}\left(\mathrm{DMSO}-\mathrm{d}_{6} \delta \mathrm{ppm}\right): 7.43(\mathrm{~d}$, $1 \mathrm{H}, \mathrm{NH}), 7.70-8.31$ (m, 10H, ArH), 8.65 (s, 1H, $\mathrm{N}-\mathrm{CH}$-pyridine $), \quad 8.84 \quad(\mathrm{~s}, \quad 1 \mathrm{H}, \quad \mathrm{N}-\mathrm{CH} \quad$ of azetidinone); Anal. Calcd. for $\mathrm{C}_{18} \mathrm{H}_{13} \mathrm{ClN}_{4} \mathrm{O}_{2}$ : C, 61.28; H, 3.71; N, 15.88: Found: C, 61.26; H, 3.74; $\mathrm{N}, 15.87 \%$.

N-(3-Chloro-2-oxo-4-(pyridine-2-yl) azetidin - 1yl)-8-methylquinoline-3-carboxamide (10):

Yield (39), m.p: $237^{0} \mathrm{C}$; IR (KBr) max in $\mathrm{cm}^{-1} 665$ (C-Cl), $1292(\mathrm{C}-\mathrm{N}), 1509(\mathrm{~N}-\mathrm{N}), 1577(-\mathrm{N}=\mathrm{CH})$, $1722(-\mathrm{C}=\mathrm{O}), 3014$ (C-H aromatic), $3320(-\mathrm{C}-\mathrm{NH})$, $3452(\mathrm{OH}) ;{ }^{1} \mathrm{H}-\mathrm{NMR}$ (DMSO-d $\left.{ }_{6} \delta \mathrm{ppm}\right): 2.21(\mathrm{~s}$, $\left.3 \mathrm{H}, \mathrm{CH}_{3}\right), 7.40(\mathrm{~d}, 1 \mathrm{H}, \mathrm{NH}), 7.72-8.30(\mathrm{~m}, 9 \mathrm{H}$, ArH), 8.60 (s, 1H, -N-CH-pyridine), $8.80(\mathrm{~s}, 1 \mathrm{H}$, $\mathrm{N}-\mathrm{CH}$ of azetidinone); Anal. Calcd. for $\mathrm{C}_{19} \mathrm{H}_{15} \mathrm{ClN}_{4} \mathrm{O}_{2}$ : C, 62.21; H, 4.12; N, 15.27: Found: C, 62.24; H, 4.14; N, 15.24\%.

N-(3-Chloro-2-(2-hydroxyphenyl)-4-oxoazetidin1-yl)-8-methylquinoline-3-carboxamide (11):

Yield (40), m.p: $245^{\circ} \mathrm{C}$; IR (KBr) $\max$ in $\mathrm{cm}^{-1} 660$ $(\mathrm{C}-\mathrm{Cl}), 1297(\mathrm{C}-\mathrm{N}), 1507(\mathrm{~N}-\mathrm{N}), 1575(-\mathrm{N}=\mathrm{CH})$, $1729(-\mathrm{C}=\mathrm{O}), 3013(\mathrm{C}-\mathrm{H}$ aromatic), $3326(-\mathrm{C}-\mathrm{NH})$, $3455(\mathrm{OH}), 3324$ (-C-NH); ${ }^{1} \mathrm{H}-\mathrm{NMR}$ (DMSO-d ${ }_{6} \delta$ ppm): 7.42 (d, 1H, NH ), 7.70-8.32 (m, 10H, ArH), 8.61 (s, 1H, -N-CH-pyridine), 8.82 (s, 1H, N-CH of azetidinone), $12.21(\mathrm{~s}, 1 \mathrm{H}, \mathrm{OH})$; Anal. Calcd. for $\mathrm{C}_{19} \mathrm{H}_{14} \mathrm{ClN}_{3} \mathrm{O}_{3}$ : $\mathrm{C}, 62.05 ; \mathrm{H}, 3.84 ; \mathrm{N}$, 11.43: Found: C, 62.04; H, 3.82; N, 11.44\%.

N-(3-Chloro-2-(2-hydroxyphenyl)-4-oxoazetidin1-yl)-8-methylquinoline-3-carboxamide (12):

Yield (38), m.p: $265^{\circ} \mathrm{C}$; IR (KBr) max $_{\text {in }} \mathrm{cm}^{-1} 667$ $(\mathrm{C}-\mathrm{Cl}), 1298(\mathrm{C}-\mathrm{N}), 1505(\mathrm{~N}-\mathrm{N}), 1573(-\mathrm{N}=\mathrm{CH})$, 
$1721(-\mathrm{C}=\mathrm{O}), 3018$ (C-H aromatic), $3329(-\mathrm{C}-\mathrm{NH})$, $3453(\mathrm{OH}) ;{ }^{1} \mathrm{H}-\mathrm{NMR}\left(\mathrm{DMSO}-\mathrm{d}_{6} \delta \mathrm{ppm}\right): 2.23(\mathrm{~s}$, $\left.3 \mathrm{H}, \mathrm{CH}_{3}\right), 7.46(\mathrm{~d}, 1 \mathrm{H}, \mathrm{NH}), 7.71-8.30(\mathrm{~m}, 9 \mathrm{H}$, ArH), 8.63 (s, 1H, -N-CH-pyridine), 8.83 (s, 1H, $\mathrm{N}-\mathrm{CH}$ of azetidinone), $12.21(\mathrm{~s}, 1 \mathrm{H}, \mathrm{OH})$; Anal. Calcd. for $\mathrm{C}_{20} \mathrm{H}_{16} \mathrm{ClN}_{3} \mathrm{O}_{3}$ : C, 62.91; $\mathrm{H}, 4.22 ; \mathrm{N}$, 11.01: Found: C, 62.94; H, 4.24; N, 11.04\%.

CONCLUSION: Compounds 1-8 exhibited mild to moderate antibacterial and antifungal activities. Cyclization of compounds 5-8 into their corresponding azetidinone congeners 9-12 markedly enhanced the antibacterial as well as antifungal activities.

ACKNOWLEDGEMENT: We are thankful to SAIF Punjab University, Chandigarh India for spectral and analytical analysis of newly synthesized compounds. We are also thankful to Department of Microbiology LLRM Medical College Meerut UP for their antimicrobial activity.

\section{REFERENCES:}

1. Maity S, Khan SA and Ahmad S: Synthesis, characterization, antimicrobial and antioxidant activity of some novel Schiff base derived from quinoline. International Journal of Pharmacy and Biological Science 2012; 2(3): 90-98.

2. Desai NC, Dodiya A and Shihory N: Synthesis and antimicrobial activity of nivel quinazolinone-thiazolidinequinoline compounds. Journal of Saudi Chemical Society 2013; 17(3): 259-267.

3. Kumar S, Goel N, Afzal O, Ali MR and Bawa S: In vitro antibacterial/antifungal screening of 2-chloroquinoline scaffold derivatives. Journal of Antibiotics Research 2015; 1(1): 1-11.
4. Wen X, Wang SB, Liu DC, Gong GH and Quan ZS: Synthesis and evaluation of the anti-inflammatory activity of quinoline derivatives. Medicinal Chemistry Research 2015; 24 (6): 2591-2603.

5. Kouznetsov VN, Rojas Ruiz FA, Vargas Mendez LY and Gupta MP: Simple 2-substituted quinolines and their anticancer activity. Letters in Drug Design \& Discovery 2012; 9: 680-686.

6. Wang SB, Deng XO, Zheng Y, Zhang HJ and Quan ZS: Synthesis and anticonvulsant activity evaluation of 8 alkoxy-5-(4H-1,2,4-triazol-4-yl)quinoline derivatives. Arch Pharm Res. 2013; 36(1): 32-40.

7. Pawar PY, Kalure SU and Kulkarni RB: Synthesis and pharmacological screening of some new azetidinone derivatives. International Journal of Pharmacy and Pharmaceutical Sciences 2012; 4(5): 464-467.

8. Dubey A, Tiwari A and Srivastava SK: Synthesis, antimicrobial and antitubercular screening of azetidinone derivatives. Journal of Chemical and Pharmaceutical Research 2013; 5 (10): 134-140.

9. Muralikrishna S, Raveendrareddy P, Ravindranath LK, Harikrishna S and Raju PAG: Synthesis, characterization and anti-inflammatory activity of indole derivatives bearing 4-oxazetidinone. Journal of Chemical and Pharmaceutical Research 2013; 5(10): 280-288.

10. Samadhiya P, Sharma R and Srivastava SK: Synthesis of azetidinone derivatives of 2-amino-5-nitrothiazole and their medicinal importance. Eur. Chem. Bull. 2013; 2(9): 611-617.

11. Desai NC, Pandya DD, Kotadiya GM and Desai P: Synthesis, antimicrobial and cytotoxic activity of 2azetidinone derivatives of pyridyl benzimidazoles. Medicinal Chemistry Research 2014; 23: 1725-1744.

12. Sarkar S, Chauhan R and Dwivedi J: Synthesis and antibacterial activity of some azetidinone derivatives containing 2-amino 6,7 substituted benzothiazole. Turk J. harm Sci. $2015 ; 12(1)$ : 39-44.

13. Greenwood D, Slack RCB and Peutherer and In JF: Medical Microbiology $14^{\text {th }}$ Edition. London 1992; 1.

14. Pai ST and Platt MW: Antifungal effect of Allium sativum extract against the Aspergillus species involved in otomycosis. Letters in applied microbiology 1995; 20: 1418.

\section{How to cite this article:}

Singh I and Kumar A: Synthesis and Antimicrobial Activity of Some Quinoline Derivatives. Int J Pharm Sci Res 2016; 7(6): 2563-67.doi: 10.13040/IJPSR.0975-8232.7(7).2563-67.

All ๑ 2013 are reserved by International Journal of Pharmaceutical Sciences and Research. This Journal licensed under a Creative Commons Attribution-NonCommercial-ShareAlike 3.0 Unported License.

This article can be downloaded to ANDROID OS based mobile. Scan QR Code using Code/Bar Scanner from your mobile. (Scanners are available on Google Playstore) 